\title{
PERANCANGAN ANTARMUKA ONLINE COURSE PADA PERANGKAT MOBILE MENGGUNAKAN TEORI USABILITY
}

\author{
Elia Zakharia ${ }^{1}$ \\ eliazakharia@gmail.com
}

\author{
Djoko Budiyanto Setyohadi ${ }^{2}$ \\ djokobdy@gmail.com
}

\author{
Y. Sigit Purnomo W. P. ${ }^{3}$ \\ sigit@staff.uajy.ac.id
}

\begin{abstract}
E-learning model can be developed into various forms according to the context of development. All of e-learning model aims to support learning process. The main objective of this study was to design online course interface that runs in mobile device using the theory of usability ISO 9241-11 in UAJY (Universitas Atma Jaya Yogyakarta). Data was collected from 55 undergraduate students of UAJY. It is used as initial state in design process. Furthermore, online course interface design created with use case diagram that adapted to activities of HTA. Nevertheless, in the design process components of interface created by the user persona and mobile device pattern, as well as guided by MGQM, which is also adapted to the limitations of this study and the conditions in UAJY. In addition, using log data collection to handle part of $M G Q M$, which related with time, steps, resources.
\end{abstract}

Keyword: online course interface, mobile device, usability, ISO 9241-11

\section{Pendahuluan}

Electronic Learning atau biasanya disebut e-learning adalah salah satu metode pembelajaran yang muncul dengan memanfaat perkembangan teknologi elektronik. Banyak pihak yang memanfaat dan mengembangkan e-learning untuk mendukung proses pembelajaran, karena sifatnya yang fleksibel, yaitu dapat diakses dimana saja dan kapan saja ((Diamond \& Irwin, 2013); (Kratochvíl, 2013); (Kratochvíl, 2014); (Sloan, Porter, Robins, \& McCourt, 2014)). Selain itu, beberapa penelitian menginvestigasi aspek-aspek yang dapat mempengaruhi kualitas dari e-learning, sehingga e-learning dapat digunakan dengan efektif, dan efesien, bahkan menimbulkan kepuasan ((He, Peng, Mao, \& Wu, 2010); (Male \& Pattinson, 2011); (H. J. Kim, Pederson, \& Baldwin, 2012); (Loh, Wong, Quazi, \& Kingshott, 2016)).

Model e-learning dapat dikembangkan ke dalam berbagai bentuk, sesuai dengan konteks dimana e-learning tersebut dikembangkan. Semua bentuk tersebut bertujuan untuk mendukung pembelajaran. Penelitian ini hanya berfokus pada online course. Konsep dari online course menurut (Picciano, 2002) adalah menyajikan bahan belajar secara online, dan menyediakan ruang bagi pelajar dan pengajar untuk berinteraksi. Desain dari komunikasi dari online course terbagi menjadi dua, yaitu synchronous communication dan asynchronous communication ((Branon \& Essex, 2001); (Hrastinski, 2008); (Kordaki \& Daradoumis, 2009); (Murphy, Rodríguez-Manzanares, \& Barbour, 2011)). Lingkungan pengembangan online course umumnya berbasis desktop atau website. Namun, saat melihat penggunaan perangkat mobile yang semakin meningkat, bahkan sudah menjadi gaya hidup atau bagian dari manusia, mengembangkan online course pada perangkat mobile menjadi peluang yang terbuka. Perangkat mobile beragam bentuknya, sehingga para desainer perlu melihat perangkat mobile dari berbagai aspek sebelum menerapkannya untuk menjadi sebuah tool perantara dari suatu pembelajaran ((Caballé, Xhafa, \& Barolli, 2010); (Wu et al., 2012)).

\footnotetext{
${ }^{1}$ Magister Teknologi Informasi, Universitas Atma Jaya Yogyakarta

${ }^{2}$ Magister Teknologi Informasi, Universitas Atma Jaya Yogyakarta

${ }^{3}$ Magister Teknologi Informasi, Universitas Atma Jaya Yogyakarta
} 
Rancangan antarmuka sangat berpengaruh terhadap orang yang menggunakannya (Cheryan, Meltzoff, \& Kim, 2011). Selain itu, desain sistem yang buruk dapat menyebabkan human-error (Norman, 2013). Oleh karena itu, saat merancang suatu antarmuka dari suatu aplikasi perlu memperhatikan sisi usability. Pengertian usability menurut (ISO 9241-11, 1998), seberapa jauh suatu produk dapat digunakan oleh pengguna untuk mencapai tujuan yang telah ditetapkan dengan efektivitas (effectiveness), efisiensi (efficiency), dan kepuasan (satisfaction) dalam konteks kegunaan yang telah ditetapkan. Usability menurut (G. Tsakonas \& Papatheodorou, 2006) berhubungan dengan ease of use, aesthetics, navigational, terminology, dan learnability. Usability dapat digunakan untuk meningkatkan kualitas dari antarmuka ((Giannis Tsakonas \& Papatheodorou, 2008); (Craven, Johnson, \& Butters, 2010)).

Saat ini UAJY (Universitas Atma Jaya Yogyakarta) sudah memiliki beberapa sarana pendukung aktivitas mahasiswa, seperti Situs Kuliah, SIATMA, SIKMA, dan ATMANESIA. Diantara keempat sarana tersebut hanya ATMANESIA yang dikembangkan pada perangkat mobile, namun ATMANESIA tidak digunakan untuk mendukung proses belajar secara langsung, fungsinya hanya untuk mengecek poin yang telah dikumpulkan mahasiswa dari aktivitas di Situs Kuliah. Tujuan utama dari penelitian ini adalah merancang antarmuka online course pada perangkat mobile menggunakan teori usability. Lingkungan pengembangannya dilakukan di UAJY. Langkah awal pada penelitian adalah mengumpulkan data, lalu membuat persona, diagram use case, dan analisis kegiatan. Langkah selanjutnya adalah membuat desain, dan mengimplementasi desain tersebut. Selain itu, penelitian ini juga membahas komponen penyusun antarmuka dari online course.

\section{Penelitian Terkait}

Penelitian ini merujuk pada buku (Vai \& Sosulski, 2011) sebagai dasar pembuatan fitur, lalu disesuaikan dengan kondisi lingkungan UAJY. Desain komunikasi online course pada penelitian ini adalah asynchronous communication. Penerapan konsep asynchronous communication dapat meningkatkan komunikasi dari pelajar yang mengalami kesusahan untuk bertanya dan berkomunikasi dengan pengajar secara tatap muka, karena pelajar dapat menyusun kalimat terlebih dahulu sebelum disampaikan, serta dapat membantu pelajar dalam mempelajari sebuah konten saat berdiskusi di grup, walaupun hal ini mengakibatkan kurangnya hubungan sosial ((Ocker \& Yaverbaum, 1999); (Järvelä \& Häkkinen, 2002); (Vonderwell, 2003)).

Dari sisi perangkat mobile, penelitian ini menetapkan screen-dimension dan input sebagai bahan pertimbangan merancang antarmuka online course. Screen-dimension adalah salah satu aspek penting dari perangkat mobile. Screen-dimension dapat mempengaruhi penglihatan dan hasil dari proses belajar seseorang ((Maniar, Bennett, Hand, \& Allan, 2008); (D. Kim \& Kim, 2012)). Hal lain yang perlu diperhatikan adalah input dari suatu perangkat. Input yang digunakan dapat mempengaruhi performa, bahkan kepuasan dari seseorang saat mengerjakan suatu kegiatan ((Travis \& Murano, 2014); (Chung \& Shin, 2015)).

Penelitian ini juga menetapkan persona sebagai dasar perancangan antarmuka. Persona adalah sebuah karakter yang dibuat untuk mewakili pengguna, dibuat berdasarkan hasil pengumpulan data, dan pada umumnya diberikan nama ((Cooper, 1999) dan (Sharp, Rogers, \& Preece, 2007)). Penggunaan persona dalam perancangan dapat meningkatkan kualitas dari suatu sistem, karena mengutamakan user-centered design ((Lerouge, Ma, Sneha, \& Tolle, 2011); (Miaskiewicz \& Kozar, 2011); (Turner, Reeder, \& Ramey, 2013); (Friess, 2015)). Penelitian ini juga menggunakan hierarchical task analysis (Annett \& Duncan, 1967), untuk menetapkan kegiatan yang dilakukan saat perancangan. Dalam merancang komponen antarmuka online course penelitian ini merujuk buku ((Neil, 2012); (Neil, 2014)). Selain itu, merujuk pada (MGQM) Measure, Goals, Questions and Metrics pada penelitian (Kantore \& Greunen, 2010) sebagai dasar merancang antarmuka yang menerapkan teori usability, lalu disesuaikan dengan kondisi di UAJY dan batasan-batasan dalam penelitian ini, seperti pada Tabel 6. MGQM pada dasarnya merujuk pada teori usability menurut (ISO 9241-11, 1998).

Tabel 6. Measure, Goals, Questions and Metrics yang Digunakan Dalam Perancangan (Kantore \& Greunen 2010) 


\begin{tabular}{|c|c|c|c|}
\hline Measure & Goal & Guideline & Metrics \\
\hline \multirow[t]{4}{*}{ Effectiveness } & Accessibility & $\begin{array}{l}\text { Ease of understanding } \\
\text { content }\end{array}$ & $\begin{array}{l}\text { Time taken to understand the } \\
\text { content }\end{array}$ \\
\hline & Help & $\begin{array}{l}\text { Ease of navigation of help } \\
\text { topics }\end{array}$ & $\begin{array}{l}\text { Is/ not easy to learn how to } \\
\text { navigate help topics }\end{array}$ \\
\hline & Interactivity & Ease of interaction & Amount of interaction required \\
\hline & Navigation & Ease of navigation & $\begin{array}{l}\text { Provide/ not provide easy } \\
\text { navigation }\end{array}$ \\
\hline Efficiency & $\begin{array}{l}\text { Effort } \\
\text { required }\end{array}$ & Amount of task effort & Amount of task effort required \\
\hline \multirow[t]{5}{*}{ Satisfaction } & Familiarity & Mental models & $\begin{array}{l}\text { Use or not familiar mental } \\
\text { models }\end{array}$ \\
\hline & Consistency & Navigation & $\begin{array}{l}\text { Rating scale of consistency } \\
\text { during navigation across system }\end{array}$ \\
\hline & Help & Sufficient help information & $\begin{array}{l}\text { Provide or not sufficient help } \\
\text { information. }\end{array}$ \\
\hline & Preciseness & $\begin{array}{l}\text { Messages } \\
\text { precision }\end{array}$ & $\begin{array}{l}\text { Provide or not precise messages } \\
\text { Rating scale of message } \\
\text { preciseness }\end{array}$ \\
\hline & Feedback & $\begin{array}{l}\text { Helpful messages } \\
\text { Suitability for all } \\
\text { users }\end{array}$ & $\begin{array}{l}\text { Provide or not helpful feedback } \\
\text { messages }\end{array}$ \\
\hline
\end{tabular}

\section{Metodologi}

\subsection{Pengumpulan Data}

Tahapan awal penelitian adalah pengumpulan data dari mahasiswa UAJY, secara khusus mahasiswa S-1. Data dikumpulkan dari 55 mahasiswa, masing-masing program studi diambil lima responden secara random. Saat ini UAJY memiliki 11 program studi S-1.

\subsection{Penetapan Persona Pengguna}

Tahap kedua, persona dibuat berdasarkan analisis hasil pengumpulan. Persona pengguna pada penelitian ini dibagi menjadi tiga karakter. Pembagian ketiganya berdasarkan data frekuensi penggunaan perangkat mobile dalam satu hari, frekuensi penggunaan perangkat mobile untuk terhubung dengan internet dalam satu hari, dan frekuensi penggunaan perangkat mobile untuk membantu pengerjaan tugas kuliah. Berikut adalah persona pengguna pada penelitian ini.
1) Adrian - expert user
Adrian adalah karakter mewakili mahasiswa UAJY yang menggunakan perangkat mobile dengan frekuensi yang sangat tinggi (high frequency).
2) Bams - medium user
Bams adalah karakter mewakili mahasiswa UAJY yang menggunakan perangkat mobile dengan frekuensi yang sedang (moderate frequency).
3) Charlie-inexpert user. Charlie adalah karakter mewakili mahasiswa UAJY yang menggunakan perangkat mobile dengan frekuensi yang kecil (low frequency).

\subsection{Pembuatan Diagram Use Case}

Tahap ketiga, pembuatan diagram use case berdasarkan analisis hasil pengumpulan data. Diagram use case adalah diagram yang digunakan untuk menggambarkan interaksi aktor (persona pengguna) dengan sistem, digambarkan pada Gambar 1. 


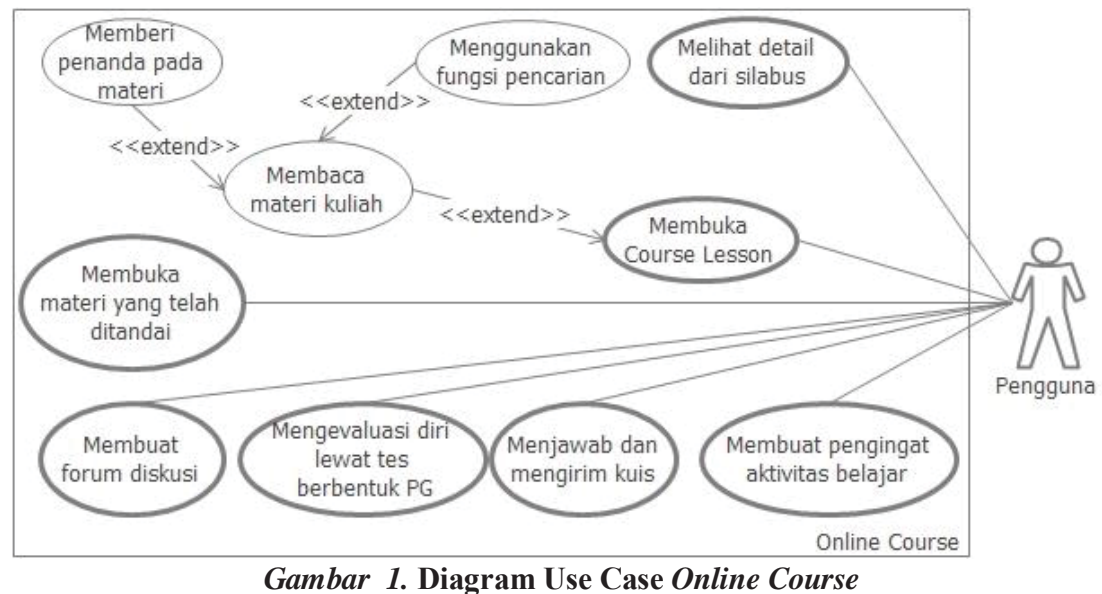

\subsection{Penetapan Kegiatan Perancangan dengan Hierarchical Task Analysis (HTA)}

Tahap keempat, pembuatan HTA berdasarkan diagram use case. HTA digunakan untuk menetapkan kegiatan yang dilakukan saat perancangan, yaitu langkah standar untuk menyelesaikan suatu kegiatan. Langkah dari suatu kegiatan yang telah ditetapkan menjadi panduan dalam perancangan antarmuka. Kegiatan yang ditetapkan pada penelitian ini ada 10, yaitu:

1) Membuka course lesson - 2 langkah.

2) Membaca materi dari mata kuliah - 3 langkah.

3) Menggunakan fungsi pencarian - 4 langkah.

4) Memberi penanda pada materi - 4 langkah.

5) Melihat detail dari silabus - 3 langkah.

6) Membuat grup forum diskusi - 4 langkah.

7) Mengevaluasi hasil belajar lewat tes berbentuk pilihan ganda - 5 langkah.

8) Menjawab kuis dan mengirim jawaban kuis -5 langkah.

9) Membuat pengingat aktivitas belajar - 4 langkah.

10) Membuka materi yang telah ditandai - 2 langkah.

\subsection{Pembuatan Desain Antarmuka}

Desain antarmuka online course dibuat berdasarkan diagram use case yang disesuaikan dengan kegiatan yang ditetapkan pada HTA. Namun pada prosesnya, komponen antarmuka dibuat berdasarkan pola pembangunan aplikasi yang umumnya dilakukan pada perangkat mobile dan persona pengguna, serta dipandu dengan MGQM yang juga disesuaikan dengan kondisi di UAJY dan batasan-batasan dalam penelitian ini. Berdasarkan Tabel 6 ada beberapa bagian dari usability yang tidak dapat dibuat secara langsung lewat antarmuka, yaitu accessibility, interactivity, dan effort required. Bagian tersebut berhubungan dengan waktu, langkah, penggunaan sumber daya. Penelitian ini menggunakan fungsi log data collection untuk mencatat kegiatan tersebut. Fungsi log data collection adalah kode-kode program dalam format bahasa pemrograman Java yang ditanamankan pada aplikasi. Fungsi tersebut mencatat setiap kegiatan yang dilakukan responden saat menguji aplikasi.

\section{Hasil dan Pembahasan}

Desain antarmuka yang telah dibuat diimplementasikan dengan Android Studio. Selanjutnya, aplikasi dipasang pada tiga perangkat mobile yang memiliki screen-dimension yang berbeda untuk melihat seberapa baik rancangan tersebut. Hasilnya rancangan antarmuka dapat menyesuaikan bentuk pada screen-dimension dengan baik. Pada Tabel 7 dipaparkan beberapa contoh hasil screen-shoot dari perangkat mobile. 
Tabel 7. Form Main Menu dari Online Course yang Ditampilan Pada Perangkat Mobile dengan ScreenDimension yang Berbeda

\begin{tabular}{|c|c|c|}
\hline $\begin{array}{l}\text { Samsung GALAXY Note } 3 \text { Neo } \\
\text { (screen-dimension: } 5.84 \text { × } 3.05 \\
\text { x } 0.34 \text { in) }\end{array}$ & $\begin{array}{l}\text { Asus Padfone } \mathrm{S} \text { (screen- } \\
\text { dimension: } 5.65 \times 2.85 \times \\
0.39 \text { in) }\end{array}$ & $\begin{array}{l}\text { Samsung Galaxy Chat } \\
\text { (screen-dimension: } 4.68 \times \\
2.33 \times 0.46 \mathrm{in})\end{array}$ \\
\hline$\Delta=\Phi \oplus \theta \quad$ \# $M=10: 43$ AM & 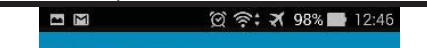 & $111: 15$ \\
\hline Online Course & Online Course & Online Course \\
\hline 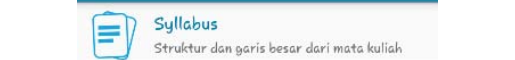 & 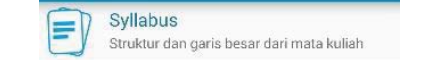 & Syllabus \\
\hline $\begin{array}{l}\text { Course Lesson } \\
\text { Paparan materidari mata kuliah }\end{array}$ & $\begin{array}{l}\text { (1) Course Lesson } \\
\text { Paparan materi dari mata kuliah }\end{array}$ & Course Lesson \\
\hline 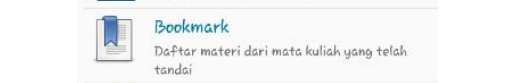 & $\begin{array}{l}\text { D. Bookmark } \\
\text { Daftar materi dari matat kuliah yang telah } \\
\text { tandai }\end{array}$ & Bookmark \\
\hline $\begin{array}{l}\text { Discussion Forum } \\
\text { Bertukar pikiran bersama teman di forum }\end{array}$ & $\begin{array}{l}\text { D. Discussion Forum } \\
\text { Bertukar pikiran bersama teman di forum }\end{array}$ & $\begin{array}{l}\text { Dastiter } \\
\text { tandal }\end{array}$ \\
\hline $\begin{array}{l}\text { Testing \& Quizzing } \\
\text { Evaluasi hasi belajarmu levant tes atau kuis }\end{array}$ & $\begin{array}{l}\text { Testing/ Quizzing } \\
\text { Evaluasi hasil belijarmu }\end{array}$ & $\begin{array}{l}\text { Discussition Forum } \\
\text { Beftica pikican bersam }\end{array}$ \\
\hline $\begin{array}{l}\text { Calendar } \\
\text { Buat pengingat activitas bel jarmu }\end{array}$ & $\begin{array}{l}\text { Calendar } \\
\text { Pengingat aktivitas belajar }\end{array}$ & $\begin{array}{l}\text { Testing \& Quizzing } \\
\text { Evaluasi hasi betajamulewattes atta kils }\end{array}$ \\
\hline (?) Help & (2) Help & Calendar \\
\hline 6 & 荌 & \\
\hline
\end{tabular}

\subsection{Komponen Antarmuka Online Course}

Pada bagian ini dibahas penggunaan komponen antarmuka online course dari penelitian ini. Komponen tersebut dirancang agar dapat menyelesaikan kegiatan yang telah ditetapkan pada HTA. Berikut adalah pembahasannya.

1) Form Main Menu.

Form ini menampilkan semua menu utama dari aplikasi online course. Implemetasi form ini terlihat seperti pada Tabel 7, dibuat dalam bentuk list menu. List menu baik digunakan untuk menampilkan menu yang membutuhkan penjelasan khusus. Pada form ini, list menu dibuat dengan deskripsi dan ikon, yang tujuannya agar menu tersebut mudah ditemukan atau diingat oleh pengguna.

2) Form Syllabus.

Form ini memberikan informasi mengenai gambaran dari perkuliahan. Form ini diimplementasikan dengan menggunakan list menu. Selain itu, form ini dilengkapi dengan beberapa menu navigasi seperti pada Gambar 2, yang bertujuan memudahkan pengguna, misalnya action menu back button, on back button press, home button, dan expandable list.

Action menu back button digunakan untuk kembali ke form sebelumnya, letak menu ini umumnya di pojok kiri atas, ikon yang mewakili menu navigasi ini adalah panah ke kiri. On back button press memiliki fungsi yang sama dengan menu navigasi sebelumnya, yaitu untuk kembali ke form sebelumnya, menu navigasi ini memanfaatkan back button dari perangkat mobile. Home button adalah menu navigasi untuk kembali ke menu utama aplikasi, letak menu ini umumnya di pojok kanan atas, ikon yang mewakili menu navigasi ini adalah gambar rumah. Expandable list pada form ini digunakan untuk menutup atau membuka informasi (bentuknya berupa kalimat-kalimat) dari suatu pokok bahasan. Ikon yang mewakili menu navigasi ini ada dua. Pertama, $\wedge$ mengindikasikan suatu pokok bahasan sedang dibuka. Kedua, $\vee$ mengindikasikan suatu pokok bahasan sedang ditutup. 


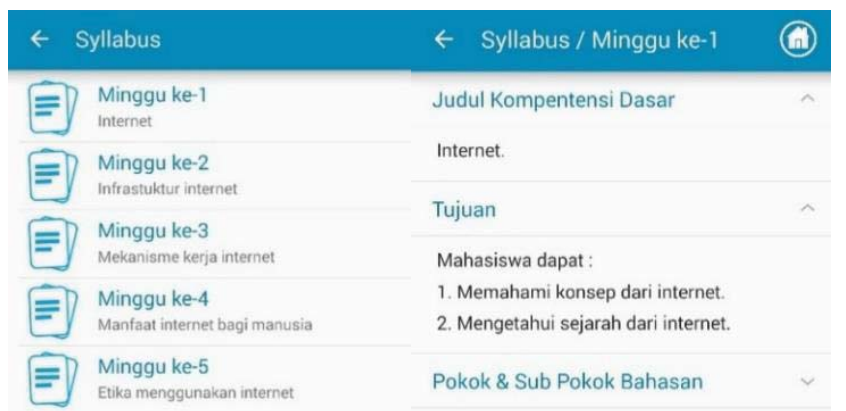

Form Course Lesson.

Gambar 2. Implementasi Form Syllabus

Form ini bertujuan menampilkan materi kuliah. Form ini diimplementasikan dengan menggunakan list menu. Form ini juga dilengkapi dengan pemberian simple dialog tooltip, yang bertujuan untuk memberikan undangan penggunaan tool. Selain itu, form ini dilengkapi dengan beberapa menu navigasi yang bertujuan memudahkan pengguna, misalnya action menu back button, back button on press, home button, dan expandable section. Form ini juga dilengkapi fungsi search, dan bookmark. Fungsi search digunakan untuk mencari kata tertentu pada materi kuliah, sesuai dengan masukan pengguna. Fungsi search dapat ditemukan di pojok kanan atas, umumnya menggunakan ikon lup. Fungsi bookmark digunakan untuk menandai suatu kalimat pada materi kuliah. Fungsi bookmark aktif atau dipanggil saat pengguna melakukan aksi ketuk dan tahan pada suatu kalimat, seperti yang umumnya diterapkan aplikasi pada perangkat mobile. Fungsi search dan bookmark juga dilengkapi dengan feedback, tujuannya adalah memberikan informasi dari suatu kegiatan. Pada Gambar 3 diperlihatkan hasil implementasi form ini.
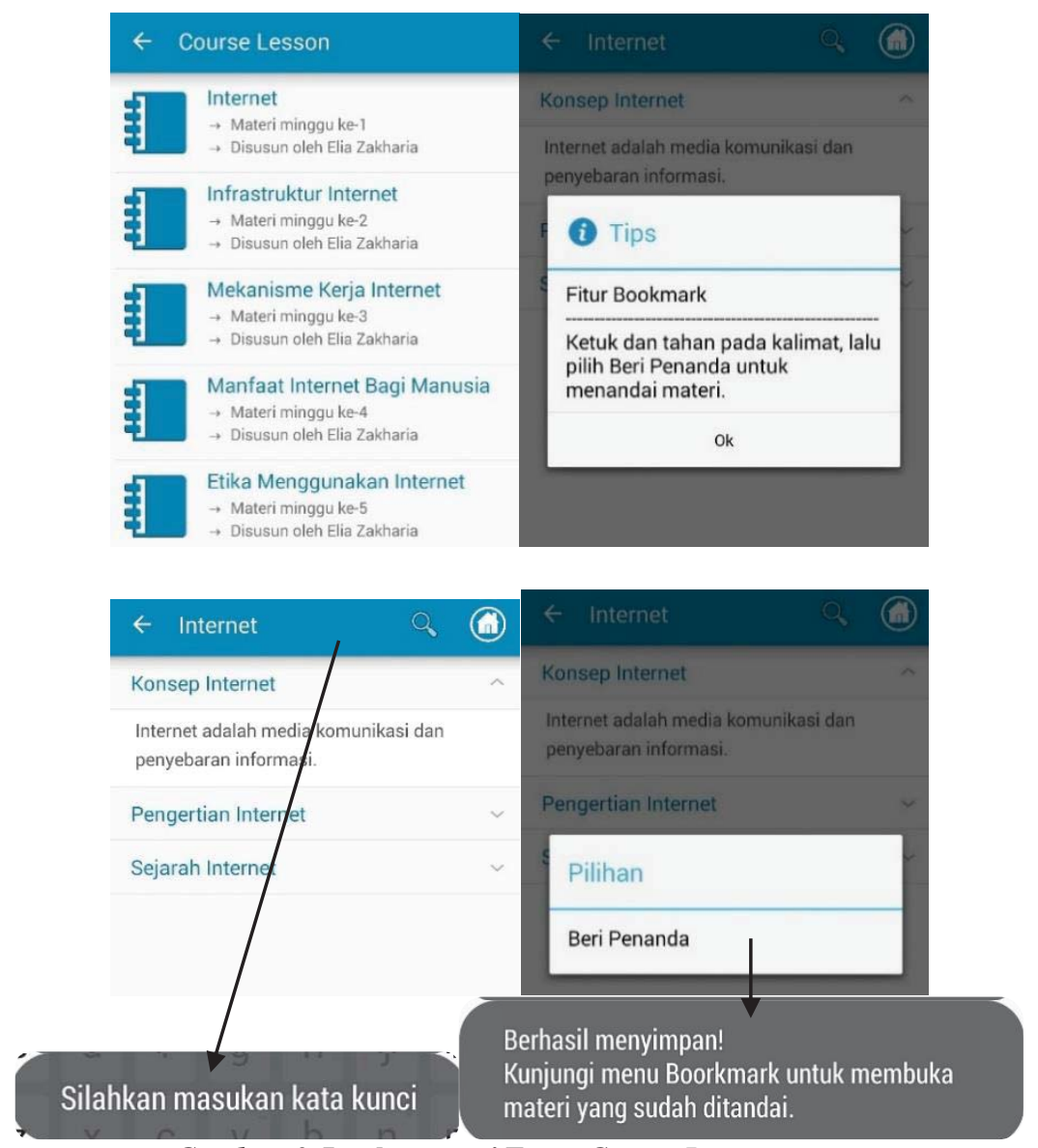

Gambar 3. Implementasi Form Course Lesson 
4) Form Bookmark.

Form ini menampilkan daftar materi kuliah yang sudah ditandai. Form ini diimplementasikan dengan menggunakan list menu. Pada bagian deskripsi dari list menu diberikan informasi tanggal penanda dan materi mana yang ditandai. Informasi tersebut bertujuan untuk memberi kemudahan bagi pengguna untuk menemukan penanda berdasarkan deskripsi tersebut. Form ini juga dilengkapi dengan beberapa menu navigasi yang bertujuan memudahkan pengguna, misalnya action menu back button, dan back button on press. Pada Gambar 4 diperlihatkan hasil implementasi form ini.

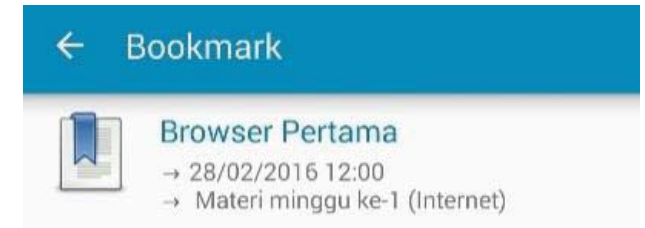

5) Form Discussion Forum.

Gambar 4. Implementasi Form Bookmark

Form ini digunakan membuat grup forum diskusi. Form ini diimplementasikan dengan menggunakan list menu. Form ini menggunakan floating button untuk menampilkan menu buat grup forum diskusi baru. Floating button pada bagian ini adalah menu navigasi yang bentuknya seperti ikon chatting. Floating button digunakan untuk membuat grup forum diskusi baru, dirancang agar memiliki sifat yang statis (fixed) pada form, sehingga pada saat pengguna menggunakan fungsi scroll vertical (melihat bagian form yang belum terlihat, baik bagian atas atau bagian bawah), pengguna dapat dengan mudah menemukan menu navigasi membuat grup baru. Form ini juga menggunakan edit text, dan check box. Edit text adalah menu kontrol yang digunakan sebagai tempat pengetikan teks. Edit text ditambahkan text hint, yaitu pentunjuk singkat yang muncul saat edit text belum dimasukan teks. Check box adalah menu kontrol yang digunakan untuk menampilkan pilihan ganda, pilihan tersebut dapat dipilih lebih dari satu. Pada Gambar 5 diperlihatkan hasil implementasi form ini.

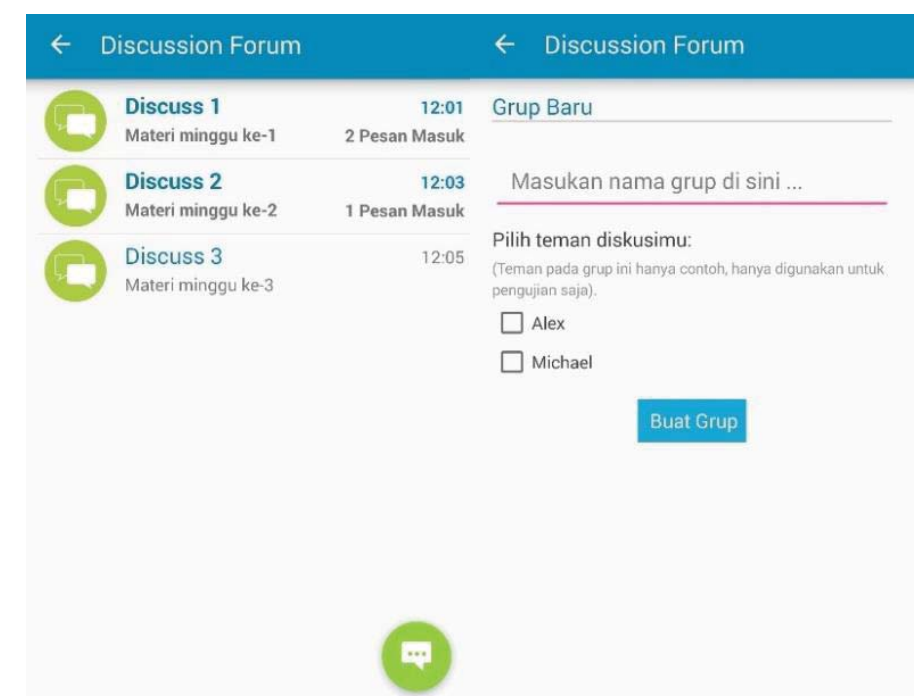

6) Form Testing.

Gambar 5. Implementasi Form Discussion Forum

Form ini digunakan untuk mengevaluasi hasil belajar lewat soal pilihan ganda. Form ini terdiri dari form question, form confirmation, dan form result. Form question berfungsi untuk menampilkan soal tes dalam bentuk pilihan ganda, diimplementasikan menggunakan kontrol radio button. Konsep radio button adalah hanya boleh memilih salah satu dari pilihan yang ditampilkan. Form confirmation muncul setelah pengguna menjawab semua soal, dan dari bagian ini pengguna dapat kembali mengoreksi jawabannya atau melihat hasil tes. Form result digunakan untuk menampilkan hasil tes 
yang telah dilakukan, serta tersedia informasi pratinjau jawaban. Selain itu, form ini dilengkapi dengan beberapa menu navigasi yang bertujuan memudahkan pengguna, misalnya action menu back button, back button on press, dan home button. Pada Gambar 6 diperlihatkan hasil implementasi form ini.

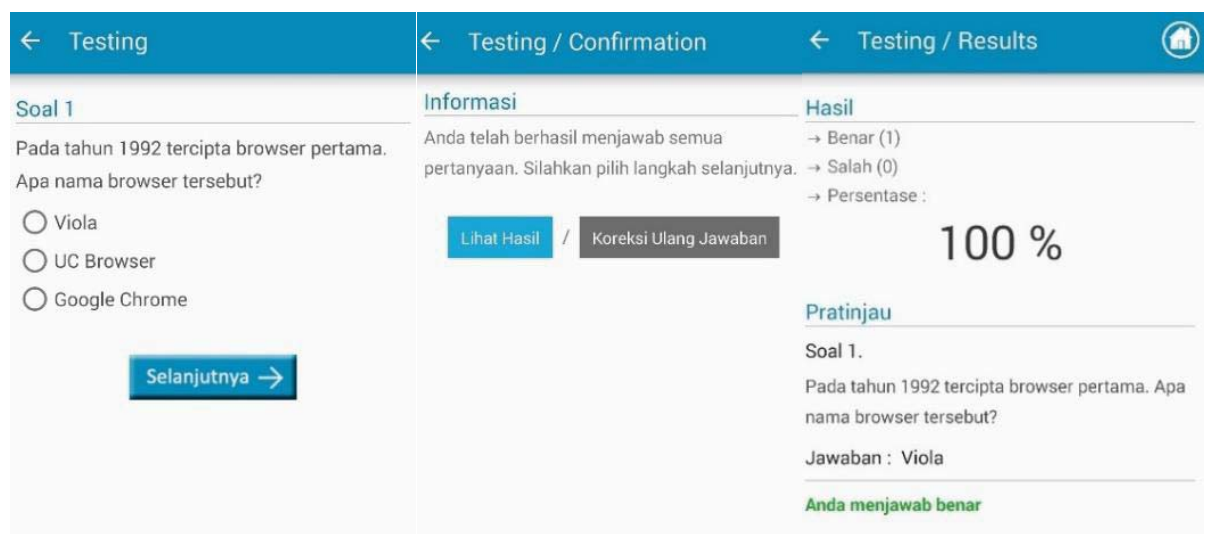

7) Form Quizzing.

Gambar 6. Implementasi Form Testing

Form ini digunakan untuk mengevaluasi hasil belajar lewat soal isian. Form ini terdiri dari form question, dan form confirmation. Form soal diimplementasikan menggunakan edit text yang mempunyai tinggi dimensi yang lebih panjang, serta ditambahkan dengan hint text. Form konfirmasi muncul setelah pengguna menjawab kuis, dan dari bagian ini pengguna dapat kembali mengoreksi jawabannya atau mengirim jawaban kuis. Form ini juga dilengkapi dengan feedback untuk memberikan informasi kepada pengguna jika jawaban kuis berhasil dikirim. Pada Gambar 7 diperlihatkan hasil implementasi form ini.

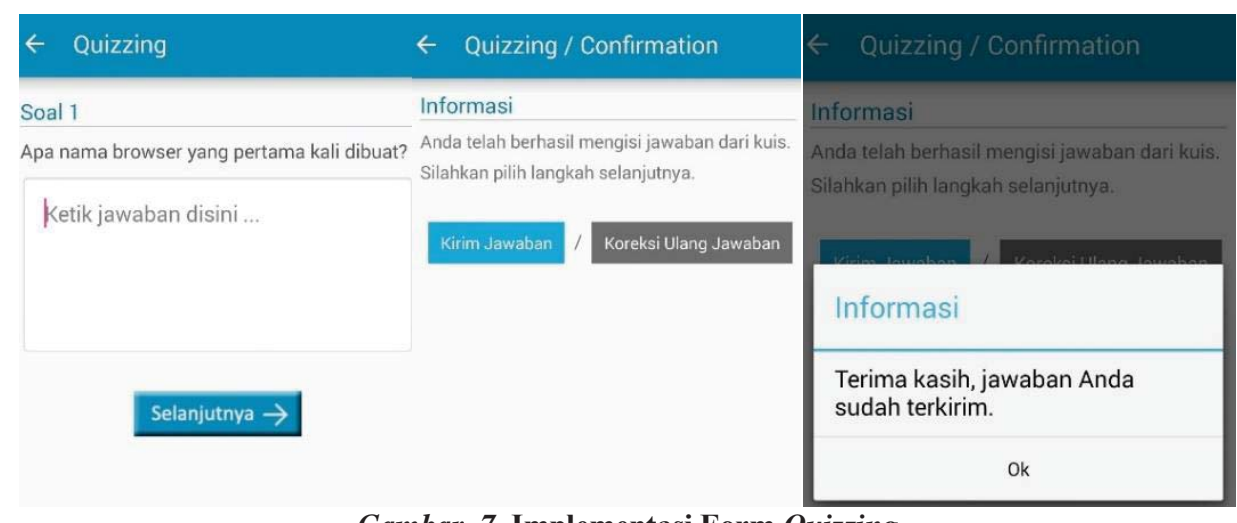

8) Form Calendar.

Gambar 7. Implementasi Form Quizzing

Form ini digunakan membuat pengingat aktivitas belajar. Form ini diimplementasikan menggunakan floating button, untuk menambahkan pengingat baru, didesain menyerupai pola aplikasi kalender pada umumnya, serta menggunakan kontrol-kontrol yang umumnya dipakai pada aplikasi, misalnya edit text yang ditambahkan text hint, dan date and time picker. Sebagai tambahan, form ini dilengkapi dengan feedback untuk memberikan informasi kepada pengguna jika pengingat baru berhasil dibuat. Pada Gambar 8 diperlihatkan hasil implementasi form ini. 


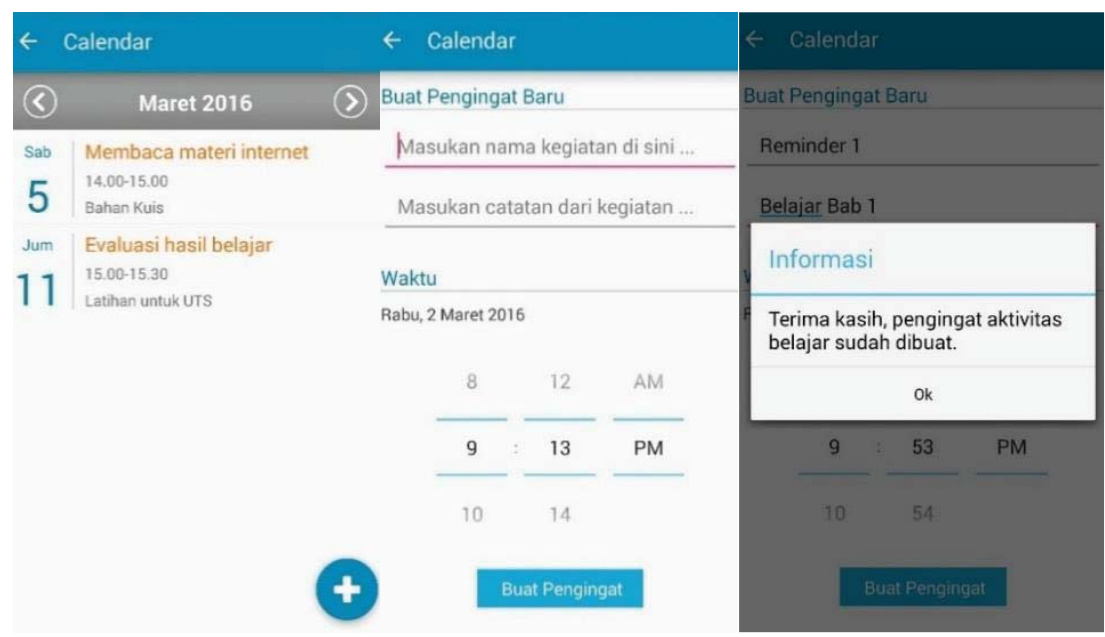

Form Help.

Gambar 8. Implementasi Form Calendar

Form ini digunakan untuk memberi bantuan kepada pengguna bagaimana cara menggunakan aplikasi dalam bentuk gambar visual. Form ini diimplementasikan menyerupai image slider. Image slider digunakan untuk mempermudah navigasi, sehingga pengguna hanya perlu menggeser ke kiri atau kanan untuk melihat informasi bantuan. Pada Gambar 9 diperlihatkan hasil implementasi form ini.

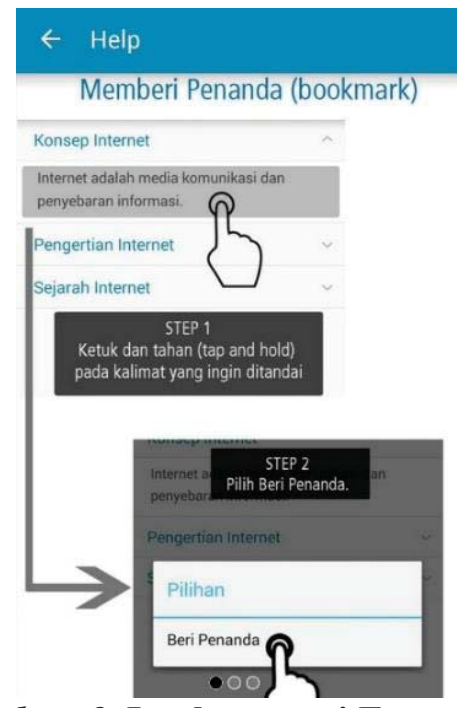

\subsection{Fungsi Log Data Collection}

\section{Gambar 9. Implementasi Form Help}

Aplikasi ini dilengkapi dengan fungsi log data collection. Fungsi ini akan mencatat setiap aktivitas penggunaan komponen antarmuka. Berikut Tabel 8 dipaparkan contoh aktivitas dari menggunakan form course lesson, serta hasil analisis dari aktivitas tersebut.

\section{Tabel 8. Aktivitas Yang Dicatat Fungsi Log Data Collection}

\begin{tabular}{l|l}
\hline Data Log & Hasil Analisis \\
\hline 2016/03/04 18:56:48 main_menu 1 & Total Waktu \\
2016/03/04 18:57:04 course_lesson 4 & 0:01:02 \\
2016/03/04 18:57:08 course_lesson/internet 5 & Total Langkah \\
2016/03/04 18:57:50 course_lesson 4 & 5 Langkah. \\
\hline
\end{tabular}

\subsection{Analisis Hasil Pengujian Usability dari Antarmuka Online Course}

Online course diuji oleh 32 mahasiswa UAJY, diambil secara acak dari setiap program studi. Konsep pengujian yang ditetapkan adalah responden menguji aplikasi dengan kondisi biasa atau natural. Namun, untuk mendapatkan data secara lengkap, responden diminta 
mengikuti skenario yang telah dipersiapkan. Berikut Tabel 9 dipaparkan metode pengumpulan data yang digunakan pada penelitian ini.

Tabel 9 Metode Pengumpulan Data

\begin{tabular}{l|l}
\hline Metode & Data Yang Diambil \\
\hline $\begin{array}{l}\text { Log data } \\
\text { collection }\end{array}$ & $\begin{array}{l}\text { Waktu, langkah, sumber daya, pencatatan kesalahan dari responden saat } \\
\text { pengujian. }\end{array}$ \\
\hline Kuesioner & Data kepuasan secara umum dari responden terhadap aplikasi. \\
\hline
\end{tabular}

Penelitian ini merujuk pada penelitian (Blanco-Gonzalo et al. 2014) sebagai panduan awal untuk menghitung usability, secara khusus terkait bagian usability yang memiliki keterkaitan dengan data yang didapat dari fungsi log data collection. Selanjutnya, menggunakan pedoman Skala Likert untuk menghitung usability yang memiliki keterkaitan dengan data kepuasan dari responden. Berikut pada Gambar 10 dipaparkan hasil penghitungan usability berdasarkan MGQM dari Tabel 6.

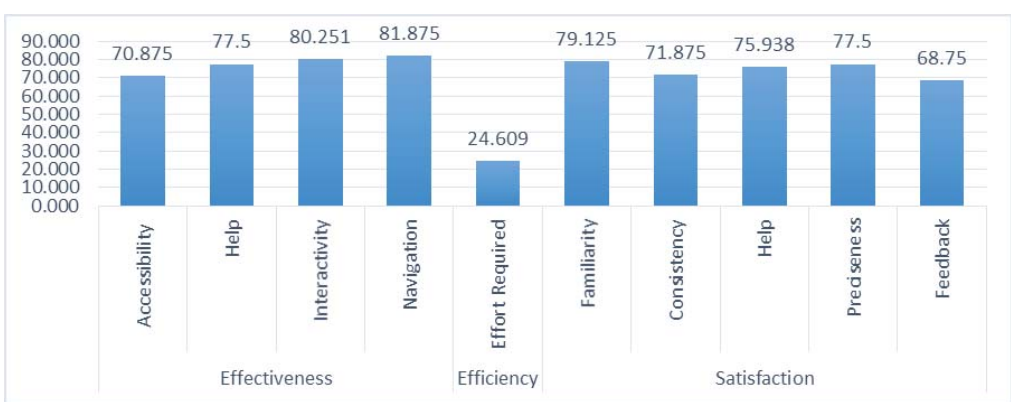

Gambar 10. Grafik Hasil Penghitungan Usability Berdasarkan MGQM

Berdasarkan Gambar 10 tingkat usability dari antarmuka yang kurang baik terlihat. Pada bagian effectiveness, hanya accesibility mendapat nilai di bawah $75 \%$. Accessibility adalah kemudahan responden mengerti kegiatan yang diberikan. Berdasarkan hasil analisis data dari log data collection seperti pada Tabel 10, waktu rata-rata responden dalam menyelesaikan semua kegiatan dari skenario pengujian lebih lambat 0:02:53 (173 detik) dari waktu tercepat dari responden, sehingga accesibility mendapat nilai $70.875 \%$. Jika waktu rata-rata responden lebih singkat, maka tingkat accesibility akan semakin tinggi. Accessibility dihitung dengan menggunakan rumus [1].

Accessibility $=\left(1-\frac{A-B}{C}\right) * 100$

Keterangan

A : Waktu rata-rata responden menyelesaikan semua kegiatan (detik)

B : Waktu tercepat responden menyelesaikan semua kegiatan (detik)

C : Waktu terlama responden menyelesaikan semua kegiatan (detik)

Pada bagian efficiency, yaitu effort required mendapat nilai 24,609\%. Hal tersebut dapat terjadi karena responden memberikan 63 percobaan tambahan dari percobaan standar untuk menyelesaikan semua kegiatan dari skenario pengujian. Percobaan standar adalah total dari kegiatan. Semakin kecil nilai effort required, maka tingkat efficiency semakin baik. Effort required dihitung dengan menggunakan rumus [2].

Effort Required $=\frac{A-B}{B} * 100$

Keterangan

A : Total percobaan yang gagal dan berhasil

B : Total percobaan standar

Tabel 10 Ringkasan Aktivitas Responden Dalam Menyelesaikan Semua Kegiatan dari Skenario Pengujian

\begin{tabular}{l|l|l|l|l|l|l}
\hline Waktu & \multicolumn{5}{|c|}{ Kegiatan } & Percobaan \\
\hline Tercepat & $0: 03: 03$ & 183 detik & Berhasil & 253 & Berhasil & 253 \\
\hline Terlama & $0: 09: 54$ & 594 detik & Gagal & 3 & Gagal & 66 \\
\hline Rata-rata & $0: 05: 56$ & 356 detik & Total & 256 & Total & 319 \\
\hline
\end{tabular}


Pada bagian satisfaction, consistency dan feedback mendapat nilai di bawah 75\%. Consistency, apakah aplikasi sudah konsisten untuk menampilkan warna, ikon, dan menu. Consistency dihitung berdasarkan data yang dikumpulkan dari kuesiner, secara khusus pada pernyataan sistem konsisten. Berdasarkan hasil analisis ada tiga responden yang tidak setuju, 11 responden netral, 14 responden setuju, dan 4 responden yang sangat setuju, sehingga tingkat konsistensi hanya mendapat nilai $71,875 \%$. Feedback, apakah aplikasi memberikan informasi yang dapat membantu responden untuk menyelesaikan suatu kegiatan. Berdasarkan hasil analisis data, ada $22(68,75 \%)$ dari 32 responden yang berhasil menyelesaikan suatu kegiatan saat pertama kali mencoba menggunakan informasi yang diberikan. Feedback dihitung menggunakan rumus [3].

Feedback $=\frac{A}{B} * 100$

Keterangan

A : Responden yang berhasil menyelesaikan kegiatan saat pertama kali mencoba.

B : Total Responden.

Penelitian ini pada dasarnya telah menggunakan beberapa teknik perancangan antarmuka yang berorientasi pada pengguna dan MGQM, sehingga diharapkan antarmuka sesuai dengan karakteristik pengguna, serta dapat membantu pengguna untuk menyelesaikan semua kegiatan dari skenario pengujian. Tetapi jika melihat analisis hasil pengujian usability, ada beberapa bagian dari aplikasi yang belum memiliki tingkat usability yang cukup baik, walaupun sebagian besar sudah memiliki tingkat usability yang baik. Bagian yang kurang baik akan dijadikan bahan rekomendasi perbaikan.

\section{Kesimpulan}

Desain antarmuka online course dibuat berdasarkan diagram use case yang disesuaikan dengan kegiatan yang ditetapkan pada HTA. Namun pada prosesnya, komponen antarmuka online course dibuat berdasarkan persona pengguna dan pola pengembangan aplikasi perangkat mobile pada umumnya, serta dipandu dengan MGQM yang juga disesuaikan dengan kondisi di UAJY dan batasan-batasan dalam penelitian ini. Selain itu, menggunakan fungsi log data collection untuk menangani bagian MGQM yang berhubungan waktu, langkah, penggunaan sumber daya. MGQM pada dasarnya merujuk pada teori usability berdasarkan (ISO 9241-11, 1998).

Desain antarmuka online course yang telah dibuat diimplementasikan dengan Android Studio. Selanjutnya, aplikasi dipasang pada tiga perangkat mobile yang memiliki screendimension yang berbeda untuk melihat seberapa baik rancangan tersebut. Hasilnya rancangan antarmuka dapat menyesuaikan bentuk pada screen-dimension dengan baik. Pemilihan dan pembahasan komponen online course didasari dari buku ((Neil, 2012); (Neil, 2014)). Penelitian ini juga melakukan pengujian usability, berdasarkan analisis hasil data, ada beberapa bagian dari aplikasi yang belum memiliki tingkat usability yang cukup baik, walaupun sebagian besar sudah memiliki tingkat usability yang baik. Bagian yang kurang baik akan dijadikan bahan rekomendasi perbaikan antarmuka online course. 


\section{Daftar Pustaka}

Annett, J., \& Duncan, K. D. (1967). Task analysis and training design. Occupational Psychology, 41, 211-221.

Branon, R., \& Essex, C. (2001). Synchronous and asynchronous communication tools in distance education. TechTrends, 45(1), 36. http://doi.org/10.1007/BF02763377

Brooke, J. (1996). SUS - A quick and dirty usability scale. In Usability evaluation in industry (pp. 4-7). CRC Press.

Caballé, S., Xhafa, F., \& Barolli, L. (2010). Using mobile devices to support online collaborative learning. Mobile Information Systems, 6(1), 27-47. http://doi.org/10.3233/MIS-2010-0091

Cheryan, S., Meltzoff, A. N., \& Kim, S. (2011). Classrooms matter: The design of virtual classrooms influences gender disparities in computer science classes. Computers and Education, 57(2), 1825-1835. http://doi.org/10.1016/j.compedu.2011.02.004

Chung, K., \& Shin, D.-H. (2015). Effect of elastic touchscreen and input devices with different softness on user task performance and subjective satisfaction. International Journal of Human-Computer Studies, 83, 12-26. http://doi.org/10.1016/j.ijhcs.2015.06.003

Cooper, A. (1999). The Inmates Are Running the Asylum. Indianapolis, IN, USA: Macmillan Publishing Co., Inc.

Craven, J., Johnson, F. C., \& Butters, G. (2010). The usability and functionality of an online catalogue. Aslib Proceedings. http://doi.org/10.1108/00012531011015217

Diamond, S., \& Irwin, B. (2013). Using e-learning for student sustainability literacy: framework and review. International Journal of Sustainability in Higher Education, 14(4), 338-348. http://doi.org/10.1108/ijshe-092011-0060

Friess, E. (2015). Personas in Heuristic Evaluation: An Exploratory Study. IEEE Transactions on Professional Communication, 58(2), 1-16. http://doi.org/10.1109/TPC.2015.2429971

He, D., Peng, Y., Mao, M., \& Wu, D. (2010). Supporting information access in e-learning by integrating digital libraries and ontology. Online Information Review, 34(5), 704-728. http://doi.org/10.1108/14684521011084582

Hrastinski, S. (2008). The potential of synchronous communication to enhance participation in online discussions: A case study of two e-learning courses. Information and Management, 45(7), 499-506. http://doi.org/10.1016/j.im.2008.07.005

ISO 9241-11. (1998). Guidance on Usability. International Organization for Standardization, 1-21.

Järvelä, S., \& Häkkinen, P. (2002). Web-based Cases in Teaching and Learning ? the Quality of Discussions and a Stage of Perspective Taking in Asynchronous Communication. Interactive Learning Environments, 10(1), $1-$ 22. http://doi.org/10.1076/ilee.10.1.1.3613

Kantore, A., \& Greunen, D. Van. (2010). An evaluation of the usability of an m-learning tool - a case study. Proceedings of the 12th Annual Conference on World Wide Web Applications, (September).

Kim, D., \& Kim, D. J. (2012). Effect of screen size on multimedia vocabulary learning. British Journal of Educational Technology, 43(1), 62-70. http://doi.org/10.1111/j.1467-8535.2010.01145.x

Kim, H. J., Pederson, S., \& Baldwin, M. (2012). Improving user satisfaction via a case-enhanced e-learning environment. Education + Training, 54(2/3), 204-218. http://doi.org/10.1108/00400911211210305

Kordaki, M., \& Daradoumis, T. (2009). Critical Thinking as a Framework for Structuring Synchronous and Asynchronous Communication within Learning Design-Based E-Learning Systems. Studies in Computational Intelligence, 246, 83-98. http://doi.org/10.1007/978-3-642-04001-6 6

Kratochvíl, J. (2013). Evaluation of e-learning course, Information Literacy, for medical students. The Electronic Library, 31(1), 55-69. http://doi.org/10.1108/02640471311299137

Kratochvíl, J. (2014). Efficiency of e-learning in an information literacy course for medical students at the Masaryk University. The Electronic Library, 32(3), 322 - 340. http://doi.org/10.1108/EL-07-2012-0087

Lerouge, C., Ma, J., Sneha, S., \& Tolle, K. (2011). User profiles and personas in the design and development of consumer health technologies. International Journal of Medical Informatics, 82(11), e251-e268. http://doi.org/10.1016/j.ijmedinf.2011.03.006

Loh, C., Wong, D. H., Quazi, A., \& Kingshott, R. P. (2016). Re-examining students' perception of e-learning: an Australian perspective. International Journal of Educational Management, 30(1), 129-139. http://doi.org/10.1108/IJEM-08-2014-0114

Male, G., \& Pattinson, C. (2011). Enhancing the quality of e-learning through mobile technology: A socio-cultural and technology perspective towards quality e-learning applications. Campus-Wide Information Systems, 28(5), 331-344. http://doi.org/10.1108/10650741111181607

Maniar, N., Bennett, E., Hand, S., \& Allan, G. (2008). The effect of mobile phone screen size on video based learning. Journal of Software, 3(4), 51-61. http://doi.org/10.4304/jsw.3.4.51-61

Miaskiewicz, T., \& Kozar, K. A. (2011). Personas and user-centered design: How can personas benefit product design processes? Design Studies, 32(5), 417-430. http://doi.org/10.1016/j.destud.2011.03.003

Murphy, E., Rodríguez-Manzanares, M. A., \& Barbour, M. (2011). Asynchronous and synchronous online teaching: Perspectives of Canadian high school distance education teachers. British Journal of Educational Technology, 42(4), 583-591. http://doi.org/10.1111/j.1467-8535.2010.01112.x

Neil, T. (2012). Mobile Design Pattern Gallery. (D. Fauxsmith \& M. Treseler, Eds.) (1st ed.). O'Reilly Media.

Neil, T. (2014). Mobile Design Pattern Gallery. (K. Ebrahim \& M. Treseler, Eds.) (2nd ed.). O’Reilly Media.

Norman, D. (2013). The Design of Everyday Things Revised and Expanded Edition. New York: Basic Books.

Ocker, R. J., \& Yaverbaum, G. J. (1999). Asynchronous Computer-mediated Communication versus Face-to-face Collaboration: Results on Student Learning, Quality and Satisfaction. Group Decision and Negotiation, 8(5), 427-440. http://doi.org/10.1023/A:1008621827601

Picciano, A. G. (2002). Beyond student perceptions: Issues of interaction, presence, and performance in an online 
course. Journal of Asynchronous Learning Network, 6(1), 21-40.

Sharp, H., Rogers, Y., \& Preece, J. (2007). Interaction Design: Beyond Human-Computer Interaction (2nd ed.). John Wiley \& Sons Ltd.

Sloan, D., Porter, E., Robins, K., \& McCourt, K. (2014). Using e-learning to support international students' dissertation preparation. Education + Training, 56(2), 122-140. http://doi.org/10.1108/ET-10-2012-0103

Travis, C., \& Murano, P. (2014). A comparative study of the usability of touch-based and mouse-based interaction. International Journal of Pervasive Computing and Communications, 10(1), 115-134. http://doi.org/10.1108/IJPCC-01-2014-0015

Tsakonas, G., \& Papatheodorou, C. (2006). Analysing and evaluating usefulness and usability in electronic information services. Journal of Information Science. http://doi.org/10.1177/0165551506065934

Tsakonas, G., \& Papatheodorou, C. (2008). Exploring usefulness and usability in the evaluation of open access digital libraries. Information Processing \& Management, 44(3), 1234-1250. http://doi.org/10.1016/j.ipm.2007.07.008

Turner, A. M., Reeder, B., \& Ramey, J. (2013). Scenarios , personas and user stories : User-centered evidence-based design representations of communicable disease investigations. Journal of Biomedical Informatics, 46(4), 575-584. http://doi.org/10.1016/j.jbi.2013.04.006

Vai, M., \& Sosulski, K. (2011). Essentials of Online Course Design: A Standards-Based Guide. Routledge.

Vonderwell, S. (2003). An examination of asynchronous communication experiences and perspectives of students in an online course: A case study. Internet and Higher Education, 6(1), 77-90. http://doi.org/10.1016/S10967516(02)00164-1

Wu, W. H., Jim Wu, Y. C., Chen, C. Y., Kao, H. Y., Lin, C. H., \& Huang, S. H. (2012). Review of trends from mobile learning studies: A meta-analysis. Computers and Education, 59(2), 817-827. http://doi.org/10.1016/j.compedu.2012.03.016 